\title{
Press freedom, ethics and the Constitution
}

Do journalists need to make a stand? As tellers of the truth and watchdogs, do those in the news media need to decide whether they are the agents of power - or of the people? And how is the journalist's code of ethics upheld? These are crucial questions about freedom of the press.

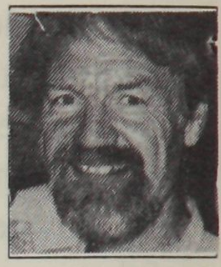

\section{By DAVID ROBIE}

ITEM: Kenya: Journalists are up in arms about two draft laws introduced in January that would establish a Government body with far-reaching powers to monitor and restrict the national news media.

ITEM: Liberia: In a reaction to a move towards censorship by the Information Ministry, the Liberian Journalists' Union has called on its members to boycott coverage of Government activities. The call has been heeded by the entire profession.

ITEM: Nigeria: Onome Osifo-Whiskey, managing editor of the magazine $T e l l$, escaped in December when State Security Service agents raided his home, but 20,000 copies of the magazine were seized later that day.

ITEM: Vietnam: The weekly Thuong Mai was suspended in December for publishing 'false and non-objective' information. The newspaper had printed an article accusing a leading official of corruption.

THESE ARE random examples from the most recent newsletter of Reporters Sans Frontières, a Paris-based worldwide organisation working to defend press freedom. ${ }^{1}$ The following paragraph wasn't - but it is bound to be in the next issue.

ITEM: Tonga: The deputy editor of the weekly Taimi 'o Tonga has been detained for 26 hours and two pro-democracy letter writers jailed for even longer without charge. Eventually the editor was charged with 'threatening' a civil servant. $^{2}$ 
Ironically, the Tongan detentions happened less than a week before a twoday seminar organised in Port Moresby to defend press freedom in Papua New Guinea in response to the Chan Government's pressure for more 'accountability'.

Yet in spite of international protests over the Tongan assault on press freedom, the case of deputy editor Filo 'Akau'ola and the letter writers was ignored by the news media executives, journalists and communications observers at Sir John Guise Stadium. Why? There were some suggestions among media executives that not enough was known about the affair.

Yet there were at least four news stories published in the Post-Courier and The National in the days leading up to the seminar organised by the fledgling Papua New Guinea Media Council. Radio New Zealand International and Radio Australia carried stories. And there were many more stories being distributed on the news agency wires. Do we assume that journalists don't read or listen? In any case, it takes just a phone call or a fax message to check out a few facts.

\section{RSF protest:}

This is what Reporters Sans Frontières director Robert Ménard had to say in a letter sent to King Taufa'ahau Tupou IV to 'strongly protest' against the raid of a newspaper office and the arrest and detention of the deputy editor:

According to our information, on February 23, Filokalafi 'Akau'ola, deputy editor of the weekly Taimi 'o Tonga, the kingdom's leading newspaper, was arrested and detained following the publication of letters concerning Minister of Police Clive Edwards.

He was kept in custody for 26 hours before being released on bail and ordered to appear in the Magistrate's Court on Wednesday, February 26, to face criminal charges that he had threatened a civil servant, under section 57 of the Tongan Criminal Code. Filini Sikuea, an unsuccessful pro-democracy candidate in last month's general election, and letter writer Vaha'akolo were also arrested and at least one of them was still in prison late on Sunday, February 25.

The police also raided the newspaper office in search of the original copy of the offending letter.

RSF acknowledges that press freedom and freedom of expression are to be practised with due regard to other laws which regulate defamation, innuendo or derogatory remarks. Nevertheless, raiding a newspaper's office. arresting and detaining a journalist, staff member and writers is clearly disproportionate to the [alleged] offence.

We protest the arrest of Filokalafi 'Akau'ola as a direct attack on press 


\section{REPORTERS SANS ITONTILKES \\ 5, ruc ficoffucy Maric $750(x)$ I'aris - lirance} Tcl: (33) $144838484 \cdot$ liax: (33) $145231151-$ Trm
King of Tonga Palace Otrice Nukualofa Tonga

Puris, 6 Murch 1996

\section{Your Excellency,}

Reporters Sans Fronticres, a worldwide indipundenl organisation working 10 defend

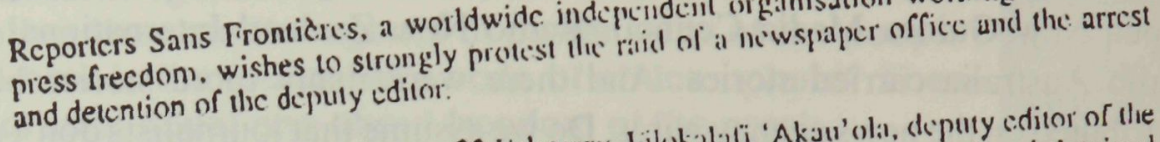

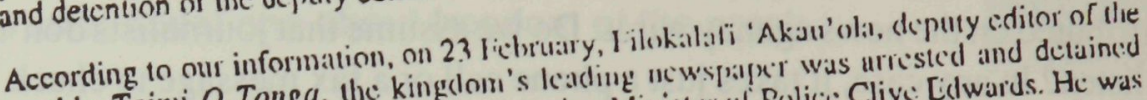
weckly Taimi O Tonga, the kingdom's keading " "ws japre was urrested and detained

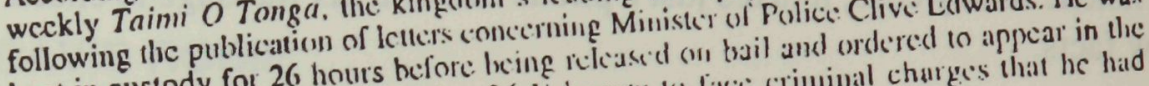

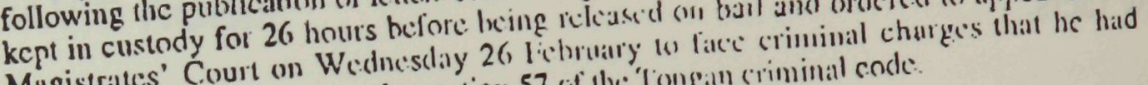
Magistrates' Court on Wednestation 57 of the 'Tongan criminal conde

thealcned a civil scivant tumdidate in last month's gencral clection.

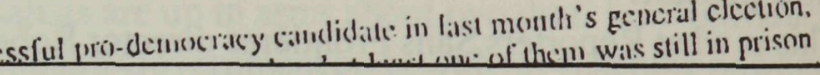

\section{RSF's protest letter to the Tongan government.}

freedom and ask that you do everything in your power to ensure that this fundamental freedom exists in Tonga.

\section{What guarantees?}

Like Papua New Guinea, Tonga's constitution guarantees freedom of speech. The point of this cautionary tale is that if journalists and editorial executives of news media would like to be supported from abroad in their current struggle to defend press freedom in PNG, then they should also be diligent about supporting others who are under threat.

Although Papua New Guinea has in the past rarely figured on the RSF lists of transgressing nations over violations of press freedom - both gaggings of the National Broadcasting Commission in the past two years were two occasions when it has been cited - it wouldn't take a great deal for this to happen. Press freedom can be a very fragile flower indeed if journalists and the public are not vigilant.

As Professor David Flint, chairman of the Australian Press Council, said at the recent seminar: 'One of the disadvantages for Australians in not having to fight for their freedom - as the Americans did - is that you always don't appreciate how precious it is. That's why the Americans in their famous First 
Amendment guaranteed the freedom of the press. They ensured that the press would be accountable to the public and no one else. ${ }^{4}$

In effect, the First Amendment not only prevents Congress from making laws abridging freedom of speech, it also prohibits laws abridging freedom of the press. Professor Flint also highlighted the safeguards within Papua New Guinea's own constitution. In the preamble, for example, are the words:

We, the people of Papua New Guinea by virtue of our inherent right as ancient, free and independent peoples do now establish this sovereign nation and declare ourselves, under the guiding hand of God, to be the independent State of Papua New Guinea.

And we assert, by virtue of that authority, that all power belongs to the people - acting through other duly elected representatives.

Under Section 46, every person in Papua New Guinea has the right to freedom of expression and freedom of the press.

How inalienable is that right? According to Chief Justice Sir Arnold Amet the right is restricted. As he says, 'The first fundamental principle [about constitutional rights] is that there is absolutely no right in life that is absolute. This is a profound truth that is so often overlooked and ignored in many deliberations and debates and assertions of rights. ${ }^{\prime}$

The Chief Justice gave the right to life being curtailed by capital punishment as an example. However, John Momis, one of the fathers of the constitution, insists that the objective of Section 46 was to be a 'formal guarantee' and a 'formal protection of the citizens' innate rights and freedoms' ${ }^{6} \mathrm{He}$ recalls that the provision was founded on "one of the great principles on which democracy rests [that] is the right to differ on any topic of discussion, be it social, economic, political, cultural or religious'.

People view any issue in different ways. We in the Constitutional Planning Committee believed firmly that they should have the right to express their own views, within very broad limits, on any particular matter, and that in principle every citizen should be free to criticise the policies of the government of the day.

The media has a particular responsibility in this regard, as unless those who wish to express independent opinions are reported in the media, their effectiveness is likely to be much reduced, and the opportunity for meaningful debate on important public issues may be lost. The formation and expression of public opinion is vital to the kind of participatory democracy we believed our people wanted. ${ }^{7}$ 
DAVID ROBIE

freedom of the press which, of course, did not mean freedom without responsibility. 'In an emerging nation such as Papua New Guinea, we believed the media had a very important responsibility to report news accurately - and to give equal opportunities and facilities for the expression by the citizens of opposing or differing views,' he said. ${ }^{8}$ Closely related to Section 46 of the Constitution is Section 51 which says

every citizen has the right to reasonable access to official documents, subject only to the need for such secrecy as is reasonably justifiable in a democratic society in respect of matters relating to national security, defence or international relations, records of meetings and decisions of the National Executive Council and other elected bodies as are prescribed by an Organic Law or an Act of Parliament.

If the Government were to truly honour this constitutional provision, a Freedom of Information Act should be legislated in keeping with the vision of the Constitutional Planning Committee.

\section{Media freedom defined}

What do we mean by 'freedom of the press'? According to the International Federation of Journalists, the major international working journalists organisation, the phrase means freedom in the collection of information, freedom of opinion and comment, freedom from interference by public authority - in accordance with the United Nations (Article 19) and European Declarations of Human Rights - including the freedom to criticise and oppose governments and political bodies and freedom in the dissemination of news by all forms of news media. ${ }^{9}$

Of the 28 'official' speakers at the recent 'Freedom at the Crossroads' seminar organised by the new Papua New Guinea Media Council, a body hastily established by the country's news media organisations to put their house in order, only one could be truly described as a working journalist. That is to say a senior journalist, Neville Togarewa, of the Post-Courier, who does not have an editorial managerial role.

No rank-and-file Papua New Guinean journalists or student journalists were invited to give their perspective although some did raise their concerns from the floor. Neither was a member of the interim executive of the now defunct PNG Journalists' Association given an opportunity to discuss the fate of this organisation, the reasons why Papua New Guinea has not been able to establish a viable journalists union protecting the profession's industrial and ethical foundations as in other countries, and where journalists should be headed 
in future. ${ }^{10}$ In the circumstances, critics could be forgiven if they regard the seminar as being more concerned with the 'freedom of the owners of the press' rather than the freedom of the press and the public's right to know per se.

However, Neville Togarewa, who was interim treasurer on the defunct PNGJA, made several crucial points in his address. He summed up the Government's decision to press for a new media law using the Constitutional Review Commission's directives as window dressing as 'rash, ill-conceived and without justification - a knee-jerk reaction based on the Government's misconceptions of the role and operations of the media'. "' His explanation for this was that the media directive had undoubtedly been forced on the Government by its 'failure to financially support its own information and communication services to better serve Government and the public'. ${ }^{2}$

Togarewa's perception is that the Government is mostly concerned about 'selection and placement' of stories. He suggests this is a matter best addressed by editorial managements adopting guidelines to assist news selection and layout rather than leaving 'obviously important editorial decisions to a select few who have their own biases and prejudices'. ${ }^{13}$

But he insists that editorial decisions should remain the preserve of editorial committees as is currently the case. The Government concerns, in his view, do not call for a Government-sponsored legislative initiative, nor do they warrant a bipartisan-supported constitutional reform of the news media.

Togarewa, reflecting a widely held view among PNG journalists, supports calls for a Freedom of Information Act to 'ensure transparency' in Government decision-making. He also refers to criticisms that the news media is allegedly 'trying to play, or take over, the role of the elected government in setting [a] national agenda - or even running the country'. He goes on to say:

I don't agree with this criticism. A Government is made up of supposedly like-minded elected representatives with common philosophies and programs, working in unison to achieve their objectives.

Journalists, on the other hand, are very individualistic, rarely agreeing with each other and collectively; they are very disorganised. This is why the [old] PNG Press Council is defunct, the PNG Journalists' Association is defunct, and the PNG Press Club is in hibernation.14

\section{Code of ethics}

The journalists' code of ethics is the third cornerstone of the self-regulation triangle, the other two being a body such as a press or media council to adjudicate complaints against the media and the legal framework governing issues such as libel and contempt of court. ${ }^{15}$ However, while a code of ethics might sound 


\section{DAVID ROBIE}

impressive on paper it does not amount to much if there is no mechanism for enforcing the code.

In New Zealand, there has been no censure of journalists under the code of ethics by their peers in the national journalists body, now known as the NZPrint, Packaging and Media Union, in the past decade. But the PPMU has now set up an ethics committee that will more closely monitor the situation along with a committee to also monitor the performance of the NZ Press Council.

In Australia, state ethics committees and a federal judiciary committee have been in existence for some years but there has been concern about their performance and the fact that deliberations and verdicts are made in secret. The Australian Journalists' Association section of the Media, Entertainment and Arts Alliance has been conducting a comprehensive overhaul of the journalists' code of ethics in the past 18 months.

In Papua New Guinea, there has been no mechanism at all for journalists themselves to deal with ethical complaints among colleagues and ethical breaches are relatively common, although less frequent than in other Pacific countries where tertiary education of journalists is not the norm. ${ }^{16}$

While the Media Council representing the publishers and broadcasters of Papua New Guinea have done a commendable job opening up public debate on media freedom issues and in starting to overhaul the self-regulatory mechanisms already in place, it now remains for working journalists themselves to get their house in order.

It would not be appropriate or desirable for journalists to be represented solely by a Media Council in whatever form. Journalists should seek to have their industrial, professional and ethical concerns addressed by an active national journalists union affiliated to either the International Federation of Journalists or the International Organisation of Journalists, as is the common practice of most countries in the world.

Like Australia, New Zealand is affiliated to the IFJ; the Philippines (several Filipino journalists work with The National), along with many developing countries, is affiliated to the IOJ. Although the PNGJA code of ethics is modelled on the old Australian code and was incorporated in the former PNG Press Council constitution and rules, it looks rather dated in the light of the Australian code reforms which are notably being carried out by journalists themselves as part of a self-regulatory process.

Some of the problems of accountability in Australia are worth highlighting. The cost of defamation actions there and the implication that someone "must have a reputation to defend' means it is only the rich who can afford this. As Monash University journalism lecturer John Tebbutt, who has considerable experience of journalism in an Asia-Pacific context, points out, 'ordinary 
citizens who have had to face misreporting and invasion of privacy have little redress at all' ${ }^{17}$ Examples he cites include:

The television reporter who, while implying he was representing the police, secured a photograph from grieving relatives for the TV news bulletins. The [Australian] Press Council found he had not said he was with the police, only that the police needed a photo, so he was not found to have done anything wrong.

Recent coverage of unsubstantiated allegations in a coronial inquest by police implicating a woman in the murder of her husband also allow little redress.

In this respect, there are real problems in the Australian media with the way 'persons aggrieved by media abuses have accessible redress'. Prominent apologies and rights of reply are obvious areas where the media could improve its relationship with citizens. ${ }^{18}$

However, there have also been several important decisions recently in Australia concerning the use of media for political expression. A High Court case in Victoria which found an implied right of freedom of political speech could indicate that criticism of political figures in good faith - in other words, not reckless or malicious and unfounded — would not be considered as defamation. ${ }^{19}$

Also, the recent Parliamentary Inquiry into Shield Laws for journalists to allow them to limit provision for the protection of sources is worth considering. (At least five Australian journalists have been jailed or fined in recent years in contempt for refusing to reveal sources in a court of law.) Probably the most used yardstick for national codes of ethics is the one adopted by the International Federation of Journalists at Bordeaux in 1954 (modified and updated since then). ${ }^{20}$ This is the norm for some 300,000 journalists worldwide represented by more than 80 national unions affiliated with the IFJ:

This international Declaration is proclaimed as a standard of professional conduct for journalists engaged in the gathering, transmitting, disseminating and commenting on news and information and in describing events.

1. Respect for truth and for the right of the public to the truth is the first duty of the journalist.

2. In pursuance of this duty, the journalist shall at all times defend the principles of freedom in the honest collection and publication of news, and of the right of fair comment and criticism.

3. The journalist shall report only in accordance with facts of which he/ she knows the origin. The journalist shall not suppress essential information or falsify documents. 
Certificate of the IFJ

Altestation de la F.I.J.

The undersigned certify that the holder is a professional journalist and request all authorities and members of the affiliated organisations of journalists to extend to the bearer every assistance and courtesy in the performance of his or her mission.

Les soussignés certifient que le porteur est journaliste professionnel et prient les et les membres des. journalistes affiliées d'accor, ,
présente ioute l'aide présente ioule laido

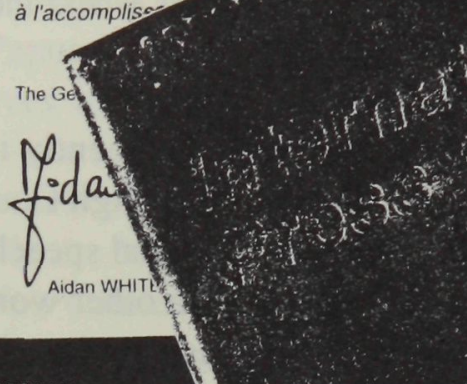
1.te $(0)$ ific

Surname ROBIE

First Names David

Date of birth $31-5-45$ Nat. $N Z$

Home address University of PNG. Port Moresby. Papua Now Guinea Union EPMU - Media

\section{An International Federation of Journalists press card.}

4. The journalist shall use only fair methods to obtain news, photographs and documents.

5. The journalist shall do the utmost to rectify any published information which is found to be harmfully inaccurate.

6 . The journalist shall observe professional secrecy regarding the source of information obtained in confidence.

7. The journalist shall be aware of the danger of discrimination being furthered by the media, and shall do the utmost to avoid facilitating such discrimination based on, among other things, race, sex, sexual orientation, language, religion, political or other opinions, and national or social origins.

8. The journalist shall regard as grave professional offences the following:

Plagiarism.

Malicious misrepresentation.

Calumny, slander, libel, unfounded accusations.

The acceptance of a bribe in any form in consideration of either publication or suppression.

9. Journalists worthy of that name shall deem it their duty to observe faithfully the principles stated above. Within the general law of each country, the journalist shall recognise in professional matters the juris- 
diction of colleagues only, to the exclusion of every kind of interference by governments or others.

The emphasis is mine. This is a crucial factor. It needs to be emphasised that unlike doctors or lawyers who have statutory accountability, journalists have no extra rights and privileges from ordinary citizens. They do not even have the protection of 'shield laws' to avoid imprisonment when defying an order from a law court to divulge a professional confidence when they are bound by their code of ethics to protect their source.

\section{Agents of power - or the people?}

According to the investigative journalist, filmmaker and author John Pilger, who has exposed many international scandals from the supply of Western arms to the genocidal Khmer Rouge in Cambodia to the Indonesian atrocities in East Timor, journalists need to make a stand.

'I believe we in the media have to decide if we are going to be agents of power - or of people. And only as the latter, can we be the guardians of history as we should be,' he says. ${ }^{21}$ Pilger argues that many journalists in developing countries work in conditions that are 'not insidious, but brutal'. As he explains:

And yet many of them see themselves as allied not with the established order, but with the people, as tellers of subversive truth. I suggest we emulate them.

Too often journalists and broadcasters in the West take refuge in the spurious notions of 'objectivity'. The great American reporter T. D. Allmann once defined objectivity as that which not only gets the facts right but understands the meaning of events, so that what we report stands the test of time.

In the past, the best journalists have written history's first draft. In the Crimea more than a century ago, William Howard Russell, The Times correspondent, wrote about the waste and blunders of sacrificial battles. In the 1950s, Ed Murrow, the American TV reporter, dared to repel smear upon smear in his reporting of the vendettas of Joe McCarthy while most of his colleagues reported the lies of McCarthy as 'objective fact' ${ }^{22}$

More recently, during the Gulf War, veteran war correspondent Peter Arnett reported from Baghdad for $\mathrm{CNN}$ on the horrors of the casualties inflicted upon Iraqi citizens while most of the press corps presented a 'star wars' spectacle for the allies. He was accused of treason - but he was right.

In this age of globalisation of information and telecommunications technology, argues University of PNG journalism lecturer Sorariba Nash, the news 


\section{DAVID ROBIE}

media is beoming increasingly privileged and powerful..$^{23}$ If society demands that the media becomes more accountable, then it is a matter of answering the question - who is watching the watchdog? To win the public trust in a democracy, the media can no longer cling to 'traditional catch cries' about a free press.

'The media must be prepared to reevaluate the substance of those catch cries and reexamine their own operations and the nature of the implicit contract they make with their audiences,' says Nash. 'And that is what I call being honest with themselves and others they serve. ${ }^{24}$

Finally, I would like to pick up on a thought raised by Neville Togarewa when he cited government concerns about the media perceived as an 'allpowerful beast prowling Waigani' and a law unto itself. ${ }^{25}$ An editor-in-chief I worked with many years ago in Kenya, George Githii, once said: 'For governments which fear newspapers there is one consolation. We have known many instances where governments have taken over newspapers, but we haven't known of a single incident in which a newspaper has taken over a government. ${ }^{26}$

\section{Notes:}

${ }_{1}^{1}$ Reporters Sans Frontières Newsletter, Paris, February 1996, pp 5-7.

2 'Tongan police detain journalists in raid,' The National, 26 February 1996.

${ }^{3}$ Reporters Sans Frontières communique to the King of Tonga, 6 March 1996.

${ }^{4}$ Flint, Professor David, 'The Australian Press Council,' a keynote address given to the 'Freedom at the Crossroads' seminar, Port Moresby, 29 February-1 March 1996.

5 Amet, Chief Justice Sir Arnold, 'Media accountability and access to redress', opening address given to the 'Freedom at the Crossroads' seminar, Port Moresby, 29 February -1 March 1996.

${ }^{6}$ Momis, John, MP, 'Why Section 46 was included in the Constitution', a paper presented to the 'Freedom at the Crossroads' seminar, Port Moresby, 29 February-1 March 1996.

${ }^{7}$ Ibid.

${ }^{8}$ Ibid.

9 See International Press Card, International Federation of Journalists.

${ }^{10}$ No general meeting or election of officers has been held since the interim executive was established in 1990 and early in 1996 the PNGJA was publicly listed by the Industrial Registrar as a trade union 'defaulter' and asked to show cause why it should not be deregistered. (The National, 18 January, 1996, p 21). The interim executive was: president Frank Senge Kolma, currently editor ofThe National (formerly press secretary to Prime Minister Paias Wingti), vice-president Sorariba Nash, lecturer in journalism, University of Papua New Guinea; treasurer Neville Togarewa, senior reporterPostCourier; and secretary Ambie Bulum, a press officer for Prime Minister Sir Julius Chan. ${ }^{11}$ Togarewa, Neville, 'Media, Government and the Constitution: A Journalist's Perspective,' a paper presented at the 'Freedom at the Crossroads' seminar, Port Moresby, 29 
February-1 March 1996.

${ }^{12}$ Ibid.

${ }^{13}$ Ibid.

14 Ibid.

${ }^{15}$ Robie, David, 'Overseas Experience: The Philippine and New Zealand Models, a paper presented at the 'Freedom at the Crossroads' seminar, Port Moresby, 29 February -1 March 1996.

${ }^{16}$ The University of PNG has produced 150 journalism graduates in PNG and the South Pacific since 1974; according to Suzanna Layton ('The demographics of diversity: profile of Pacific Island journalists,' Australian Studies in Journalism, Vol 4, 1995, p 137), 68 per cent of PNG journalists have a tertiary qualification, in contrast to Fiji, for example, which has 16 per cent. See David Robie, 'Electronic Newspaper: Uni Tavur and Print Media Education at UPNG,' a paper presented at the 'Freedom at the Crossroads,' seminar, Port Moresby, 29 February-1 March 1996.

${ }^{17}$ Tebbutt, John, 'PNG media accountability,' letter toUni Tavur, March 8, 1996, p 4. ${ }^{18}$ Ibid.

${ }^{19}$ Theophanous vs Herald and Weekly Times [1993] 124 Australian Law Reports 1; see Third Edition of Media Law in Australia, Armstrong Lindsay Watterson, Oxford University Press.

${ }^{20}$ The 'Declaration of Principles on the Conduct of Journalists' adopted at the Second World Congress of the IFJ at Bordeaux, France, April 25-28, 1954; amended at the 18th IFJ World Congress, Helsingör, 2-6 June 1986. See IFJ International Press Card.

${ }^{21}$ Pilger, John, 'The Media: Censoring the Truth,' a keynote address at the presentation of the 11th New Zealand Media Peace Awards in Auckland, November 1994.

${ }^{22}$ Ibid.

${ }^{23}$ Sorariba, Nash, submission as consultant to the Constitutional Review Commission media committee; excerpt published as 'Changing old media habits,' inUni Tav'ur. 8 March 1996, p 7.

${ }^{24}$ Ibid.

${ }_{25}$ Togarewa, op.cit.

${ }^{26}$ Robie, David (ed), Nius Bilong Pasifik: Mass Media in the Pacific. Port Moresby: University of PNG Press, 1995, p 10.

$\square$ David Robie is lecturer in journalism at the University of PNG's South Pacific Centre for Communication and Information in Development (SPCenCIID). he presented this paper at the 'Twenty Years of the PNG Constitution' Conference organised by the Law Faculty, UPNG, and the National Institute for Continuing Legal Education at Granville Motel, Port Moresby, 28-30 March 1996. drobie@pactok.peg.apc.org 